This is a self-archived version of an original article. This version may differ from the original in pagination and typographic details.

Author(s): Nykänen, Nooa

Title: Competing institutional logics in Soviet industrial location policy

Year: 2019

Version: Accepted version (Final draft)

Copyright: (c) Taylor \& Francis, 2018

Rights: In Copyright

Rights url: http://rightsstatements.org/page//nC/1.0/?language=en

Please cite the original version:

Nykänen, N. (2019). Competing institutional logics in Soviet industrial location policy. Eurasian Geography and Economics, 59(4), 314-339. https://doi.org/10.1080/15387216.2019.1581631 


\title{
Competing institutional logics in Soviet industrial location policy
}

This is an Accepted Manuscript of an article published by Taylor \& Francis in Eurasian Geography and Economics on 14.02.2019, available online: https://www.tandfonline.com/doi/full/10.1080/15387216.2019.1581631

\author{
Nooa Nykänen \\ Department of History and Ethnology \\ University of Jyväskylä \\ Jyväskylä, Finland \\ nooa.nykanen@jyu.fi
}

\begin{abstract}
The Soviet legacy has been widely demonstrated to have had negative impacts on the regional and economic development of Russia. This article studies the mechanisms of competing institutional logics in Soviet industrial location policies as a source of this adverse heritage. The results indicate that prolonged competition between three institutional logics complicated the adoption and practice of consistent industrial location strategies and contributed to structural problems in economic geography. An analysis of Soviet institutional logics demonstrates parallel forms of competition and coexistence with findings from other institutional environments, paving the way for a broader theoretical analysis of Soviet organizations and institutions.
\end{abstract}

Keywords: Soviet Union; Institutional logics; Industrial location; Economic geography; Economic history 


\section{Introduction}

The Soviet legacy, specifically its institutions, infrastructure and industrial structure, are often identified as key obstacles in modernizing the Russian economy (Bradshaw 1991; Spulber 2003, 234-235; Bradshaw \& Connolly 2016). Institutionally, the Soviet model of socialist economy developed into a particular organizational form of central planning, accompanied by direct interventions from the state authorities (Kornai 1992). Structurally, the industrial organization of the Soviet Union was characterized by institutional complexities of vertical integration and uneven spatial distribution. The decline of the Soviet economy has been explained by variety of factors, ranging from chronic shortage (Kornai 1992) and extractive institutions (Acemoglu \& Robinson 2013) to a lack of innovations (Amann \& Cooper 1982; Ericson 1991; Spulber 2003). Michael Bradshaw (1991) has connected the lack of innovation to conservatism in Soviet production, noting that improvements in production methods were not rewarded sufficiently to risk possible deficiencies in existing production rates. This conservatism and unwillingness to introduce changes that could alter the existing structures in power and production hierarchies extended to the higher ranks of the political and economic administration (Grossman 1962; Peters 2016). Several reforms aimed to tackle these issues, but they resulted in a failure to introduce fundamental changes to the industrial structure or to initiate economic success (Hoeffding 1959; Amann \& Cooper 1982, 12; Autio-Sarasmo 2016).

The development of economic geography in the Soviet Union has also been marked by structural conservatism and resistance to modernization. Hill and Gaddy (2003) have strongly argued that the costly industrialization and settlement of Siberian peripheries caused severe obstacles for industrial reforms and continue to impede political and economic development. Even today, Russia's orientation towards traditional heavy industry and resource sectors remains strong (Hill \& Gaddy 2003; Markevich \& Mikhailova 2013; Bradshaw \& Connolly 2016). The origins of this development derive from early Soviet industrialization campaigns, which transformed the Soviet economic geography and organization during the late 1920s and 1930s and led to the emergence of consequent industrial location principles (Koropeckyj 1965). Although the post-Stalinist era prompted numerous reforms in the Soviet economy, the outlines of the country's industrial location policy remained largely in place (Koropeckyj 1965; Nove 1986; Dellenbrant 1986). According to Kofanov and Mihailova (2015), the consequent industrial distribution based on raw material proximity overlooked the creation of knowledgeintensive agglomerations, which are necessary for high-tech industries. Transformations in economic geography are strongly path dependent (Krugman 1991; Martin \& Sunley 2006), 
suggesting that outcomes of those locational decisions and strategies still delimit the ways Russia can coordinate and develop its economy.

Against this background, it is somewhat surprising that the institutional foundations of Soviet industrial location principles and consequent policies have received little attention from scholars. Motivated by recent conceptual and theoretical development in organization studies, this article assumes an institutional logic perspective (Thornton et al. 2012) to study the institutional environment of Soviet industrial location decisions by exploring underlying rationales of Soviet economic geographical strategy. Specifically, I argue that the industrial location policy in the Soviet Union was influenced by competing institutional logics, which survived for several decades and manifested in the so-called location principles that were identified and analyzed by Western scholars during the Cold War (e.g. Koropeckyj 1965; Holzman 1957; Hooson 1972; Huzinec 1977). Based on extensive qualitative analysis of industrial location discussions, the core argument of the paper is that competition between these institutional logics partially accounted for the inconsistent location strategies, eventually contributing to the adverse economic geographical structure of the country. The results extend Hill and Gaddy's (2003) analysis of how industrial misallocation took place during Soviet times by concentrating on particular rationales for adopting and sustaining such an industrial location strategy. The presented framework of competing institutional logics also contributes to the study of regional development trends in Russia, where Kinossian (2013) especially has highlighted the institutional legacy of socialism as a component of the formation and practices of new regimes and observed the enduring presence of competing logics in decision-making. The notion that similar institutional mechanisms still complicate the adoption of consistent territorial development policy in post-Soviet Russia underlines the need to explicate the dynamics of corresponding competing logics during the Soviet era.

The contents of the article are organized as follows. Section 2 discusses the concept and theory of institutional logic and its use in studying the Soviet context, also specifying how the analysis of the study is related to previous scholarly work on the topic. Section 3 provides a short historical account of Soviet economic geographical development. Section 4 presents a framework of three competing institutional logics in Soviet industrial location policy based on an extensive review and analysis of Soviet and Western economic geography publications. The contradictory objectives and mutual competition of these logics are analyzed in section 5 and the outcomes of this interaction in section 6. Section 7 summarizes the findings, discussing the 
contributions, implications and limitations of the article, while pointing out possible avenues for further research.

\section{The concept and theory of competing institutional logics}

The concept of institutional logics has drawn intense attention within organization studies since the 1990s (Friedland \& Alford 1991; Thornton et al. 2008; 2012). Thornton et al. (2008; 2012, 2) define institutional logics as "socially constructed historical patterns of cultural symbols and material practices." These symbols and practices include assumptions, values and beliefs by which individuals and organizations provide meaning to their daily activities, organize time and space, and reproduce their lives and experiences (Thornton et al. 2012, 10). Institutional logics are used by organizations and individuals to elaborate and manipulate their content through interpretation, but logics also constrain and direct how means and ends of behavior are selected (Friedland \& Alford 1991; Thornton et al. 2008, 101). On a supra-organizational level, logics operate as material-symbolic languages (Thornton et al. 2012; Friedland 2012), helping to explain connections that create a sense of common purpose and unity within organizational fields (Reay \& Hinings 2009, 629).

A meta-theoretical notion that institutional logics are historically contingent (Thornton \& Ocasio 2008, 108-109) is central for the purposes of this study. Although the organizational field is commonly organized according to a dominant logic (Strang \& Meyer 1993; Lounsbury 2002), the simultaneous existence of multiple logics is possible over lengthy periods of time (Scott 2008; Thornton \& Ocasio 1999; Purdy \& Gray 2009). The degree of ontological conflict between logics determines whether simultaneously existing institutional logics manifest, on an organizational level, as coexistence or competition of managerial practices and organizational forms. Power struggles over political status deviate from the competition of logics in the sense that the theory of institutional logics perceives these organizational actions as derivatives from existing institutions (Thornton \& Ocasio 1999; Thornton \& Ocasio 2008, 111) and actors' understanding of prevailing institutional logics. Three different ways have been identified as to how competing logics may operate in the organizational field (Reay \& Hinings 2009, 645; Goodrick \& Reay 2011). First, the rivalry takes the form of a series of battles where actors supporting the winning logic achieve dominance and contradictory logics lose relevance. Second, the rivalry of logics avoids confrontations and takes place through covert operations, where actors attempt to gradually elevate their logic to preeminence or to undermine the 
currently dominant logic. Third, the coexistence of competing logics through collaborative actions at the micro level leads to the enabling of institutionalized arrangements.

The institutional logic approach follows the conceptualization of society as an interinstitutional system introduced by Friedland and Alford (1991) and developed by Thornton (2004) and Thornton et al. (2012). The inter-institutional system is composed of multiple sectors representing different sets of expectations for social relations and human and organizational behavior. Each of these sectors provides a different source of rationality, potentially leading to the emergence of contending institutional logics. The inter-institutional system of society determines different institutional orders with their own characteristic logics, which interact with institutional orders, and their logics, at organizational and individual levels. As an example, Friedland and Alford (1991) decomposed Western society into the orders (and their corresponding logics) of the capitalist market, the bureaucratic state, democracy, family and Christian religion. In the Soviet Union, the main institutional sectors at the societal level included the economic system based on planning, the state and Party bureaucracy, socialism and ethnic nationalism. In this study, the Soviet Union represents the societal level of analysis, and the sphere of industrial location decision-making the organizational level of analysis. This perspective adopts Kornai's (1992, 33-61) definition of the Soviet system as an array of organizations under distinct formal and informal rules of power and ideology. Industrial location decision-making, the central object of this study, took place at an organizational level, specifically in planning organs and industrial ministries, which were subordinate to Party directives (Zaleski 1980). Thus, Soviet industrial location policy constituted an institutional field, one which was continuously influenced by the logics of Soviet society.

Institutional logics are connected to organizational decision-making by directing the attention of responsible actors to problems that reflect their understanding of self-interest and collective identity in institutional environments (Thornton \& Ocasio 2008, 114), limiting the set of alternatives available for strategic choice based on what is considered appropriate and legitimate within the sphere of given institutional logic. Conflicting interpretations of these issues may lead to the formation of several organizational coalitions (Greve \& Zhang 2017), each of whom commits to a certain logic and competes with others to implement their own in decision-making processes. This is consistent with Dellenbrant's (1986, 26-27) view that Soviet regional decision-making took place within a bureaucratic system consisting of different, competing groups. During the 1920s and 1930s, the institutional field of Soviet 
industrial location policy began to emerge (e.g. Purdy \& Gray 2009), reinforcing the formation of multiple competing logics and thus serves as a relevant starting point for this study.

\section{Elements of Soviet industrial location: Principles, priorities and logics}

The analysis of logics in this article builds on previous studies of Soviet industrial location. These studies have recognized a set of principles behind industrial location policy consisting of military needs, economic rationalization and regional equalization (Koropeckyj 1965; Rodgers 1974; Huzinec 1977). A criteria for prioritizing was necessary because investment demand constantly exceeded distributable resources (Dellenbrant 1986; Kornai 1992). During the Cold War, Western literature reviewing Soviet development remained inconclusive in its conceptualization of the phenomena. The principles identified were often categorized into numerous sub-parts (e.g. Koropeckyj 1965, 54-55), and the order of priority for the principles could not be established while the existence of theoretical underpinnings behind location decisions was questioned (Rodgers 1974; Huzinec 1977). A similar incoherence plagues Soviet publications on the theme, especially since military considerations were omitted from the analysis for political reasons (Samuelson 2011, 128-129). Despite occasional statements of set principles in locational planning, the Soviet textbooks hardly described the realities of economic geography critically or conclusively.

Koropeckyj (1965) and Dellenbrant (1986) have classified the principles of Soviet location theory into three groups: (1) purely economic, (2) combined economic, social and political and (3) purely political. The second category corresponded closely with the principle of regional equalization, whereas the third category was close to synonymous with military considerations. However, much space in his analysis is devoted to a discussion of the internal contradictions of these groups as well as the distinction between locational theory and locational policy. The former was seen as strongly reliant on Alfred Weber's (Weber 1909) theory of production and transport costs, even though Weber's theories were officially dismissed as incompatible with Soviet ideology. Although Weberian principles had a large influence in Soviet location principles, they were subordinate to the political objectives of the Communist Party, which ultimately decided the locational policy (Koropeckyj 1965, 52-54).

Approaching the issue of Soviet industrial location through the framework of institutional logics develops the discussion of principles in the following ways. First, the institutional logic perspective allows internal contradictions between principles and their implementation by highlighting the cognitive element of logics, which consist of socially constructed and 
historically contingent values, assumptions and beliefs. Instead of providing unambiguous sets of guidelines for locational decision-making, each logic directs and constrains the selection of means and ends (in this case, the application of location principles) based on interpretations of institutional environments. Second, analyzing Soviet industrial location policy as outcomes of institutional logics bridges the gap between seemingly contradictory location theories and location policies. Whereas the historical outcomes of Soviet industrial location decisions greatly deviate from theoretical principles presented in Soviet publications, the institutional logic perspective explains this difference by emphasizing how theoretical location principles reflect the operation of institutional logics as material-symbolic languages, whereas the actual policy reflects the environment of conflict between different logics and their constraints on decision-making processes. Here, the framework of coexisting institutional logics as constellations (Goodrick \& Reay 2011, 399), is particularly useful to study the decision-making environment, because it explains how multiple logics or principles may combine as patterns during specific situations (industrial location decisions) to produce an outcome, which reflects the mode of their coexistence at that time. Location decisions do not necessarily reflect location principles (Dellenbrant 1986, 46), but they certainly follow some sort of combinations of logics. Outlining the outcomes of decision-making process as an outcome of competing logics makes it possible to understand how emphases changed in Soviet location planning due to changes in inter-relations between logics and how the logics themselves developed by diffusing feedback from economic geographical development and changes in institutional environment. Third, assessing the history of Soviet industrial locations as outcome of competing institutional logics instead of locational principles provides a possible link between the Soviet legacy and post-Soviet regional policy. The Soviet locational principles, as defined by Koropeckyj and others, were established for the institutional environment of the socialist economic system, which has ceased to exist and thus does not offer direct analytical relevance for studying the economic geographical environment of post-Soviet countries. However, whereas the Soviet location principles have collapsed, the institutional logics and their material-symbolic languages have not. Recognizing the long-lasting influence of institutional logics on industrial location strategy enables further study of the dynamics and decline of their constituent elements, making it possible to analyze the historically contingent impact of logics on postSoviet development. Although this avenue has not been pursued extensively in this article due to space constraints, it might provide a useful research opportunity to study the extent to which similar logics behind location principles have endured in the transition to post-Soviet countries. 


\section{Historical context of Soviet economic geography}

Despite the devastating effects of World War I and the Russian Civil War on the national economy, the remnants of Czarist-era industry defined the direction of early Soviet strategies for economic development. Geographically, technology and industrial infrastructure was unevenly distributed and connected to the railroad network. Industrial centers, such as Donbass, Baku and Lodz, emerged in the peripheries, representing isolated points of modernity while political and administrative power remained in St. Petersburg and Moscow (Nove 1969; Owen 1995).

Significant geographical redistribution of the Soviet industry took place when the Bolsheviks instated their power during the first half of the 20th century (Nove 1969). In many ways, the industrialization efforts were carried out without antecedent examples. The nationwide electrification program, GOELRO, ${ }^{\mathrm{i}}$ was one of the first and most essential industrial goals for the Bolsheviks. Started in the 1920s, GOELRO aimed at building large regional electric power stations and systems which would pave way for a new, long-term economic division of territorial regions (Saushkin 1962; 1966). GOSPLAN set up a special commission in 1921 to define such economic regions. Initial plans in 1920-21 identified 8 to 10 major economic regions, before a scheme comprising 22 regions was approved in 1922 by the All-Russian Central Executive Committee (Saushkin 1966, 9-15).

At the 14th Party Congress in 1925, Stalin introduced the "general line" of Soviet economic development, explaining that, in order to avoid economic dependence on capitalist countries, the Soviet Union would have to change the structure of its economy and invest in self-sufficient heavy industry and machine-building instead of relying on agricultural exports (Kotkin 1997, 30). The construction of the Ural Kuznetsk Combine (UKC) came to epitomize the characteristics and strategic goals of Soviet industrialization campaign under Stalin's leadership. In 1920, VSNKh (Supreme Soviet of the National Economy) began planning the UKC project to develop coal mining and metallurgical industries in the Ural mountain range. The idea behind the massive project was to combine the coal reserves in Western Siberia and ore reserves in the Urals under one industrial complex. UKC received heavy investments during the first and second five-year plans, accounting for approximately one-third of all industrial investments between 1932 and 1937 (Holzman 1957). Nevertheless, the production output fell short of the planned goals and large quantities of steel and iron products were of poor quality and unusable outside production quota calculations (Kotkin 1997, 62-65). The 
costs of transporting raw materials and final products with inadequate and congested railroad lines made UKC a hugely expensive project and after the second five-year plan, its emphasis declined drastically. No new production units were built in Magnitogorsk after 1936 and the relative, though not absolute, production output decreased after World War II (Holzman 1957, 383-387). The costs of World War II, both social and economic, were immense for the Soviet Union (Davies 1998, 58-67). In the 1950s, displacement of evacuated industries to the eastern regions had ended, while industrial potential in western Russia reached its prewar level.

Despite the relatively quick economic recovery after World War II, the structure and distribution of industrial geography contained problems that have since become intrinsic and resisted modernization efforts. Dienes (1983) categorized Soviet economic regions of the 1950s into three prevailing types: old economic cores requiring modernization and diversification; environmentally harsh peripheries which contained promising future resources, but remained insufficiently integrated into national economic system; and overlooked rural areas with a large population, but unutilized in industrial potential (Dienes 1983, 219). Jan Åke Dellenbrant (1986, 12-13) has conceptualized the Soviet regional problem as "triangular," where development of Siberian, Central Asian and European macro-regions was partly mutually exclusive and required investment priorities. In the 1960s and 1970s, intensive investments were directed to less-developed and peripheral regions, overlooking economic arguments in favor of equalizing regional disparities (Dienes 1972; Kumo 2004). This movement did not severely alter the geographical pattern in the form of new industrial districts, but strengthened already established plants and regions (Mellor 1982, 142, 153). Several relocations to economically more efficient centers were adopted only from 1975 onwards, when industries in numerous peripheral regions (north Caucasia, far east, central Asia) began to decline (Kumo 2004). As recently observed by Bradshaw and Connolly (2016), Western economic geographers predicted at the turn of 1980s that Far Eastern regions might profit from the expansion of foreign trade with Asian countries, but this development did not commence. Overall, however, the adverse structure of industrial geography has remained in similar form until modern times (Hill \& Gaddy 2003; Markevich \& Mikhailova 2013).

\section{Competing institutional logics in Soviet location policy}

This chapter discusses three institutional logics-military, economic and regional—which competed for field-level dominance in the Soviet economic regionalization and influenced the environment of industrial location decisions. Each logic was translated into the institutional 
field in the form of theories, frames and narratives (Thornton et al. 2012, 152), which utilized different types of rationality (Kalberg 1980). This prompted their different approaches to industrial geography, development possibilities and expectations of policy outcomes. While the logics had historical roots in the development of earlier periods, the societal and economic development experienced during the Soviet era extended and modified epistemological boundaries of logics, leading to the emergence of new cultural symbols and material practices.

One distinct category, bureaucratic logic, does not feature in the analysis, despite its overwhelming impact within the Soviet inter-institutional system (Kornai 1992). Although bureaucratic logic was perhaps the most dominant institutional logic directing Soviet industrial investments and planning mechanism after World War II, it had no specific or verified preferences in the initial industrial site selection process. Instead, different levels of bureaucracy adopted perspectives and principles of argumentation from those institutional logics they felt best fit their interests. Bureaucratic support for one of the institutional logics could be decisive in attaining dominance over the others in location decisions, though its effective impact is difficult to evaluate.

The inclusion and analysis of three individual logics is based on an extensive qualitative review of Soviet and Western industrial location literature. The purpose of this work has been to assess the role of institutional logics as macro-level constituents of Soviet industrial location policy and to analyze the impact of competing logics for Soviet industrial development at large. This boundary condition warrants, on the one hand, the inclusion of Western publications to complement Soviet discussions (especially in the case of military logic) and, on the other, the exclusion of micro-level antecedents of logics and their conflicts within the Soviet system, which could be studied using archival materials highlighting specific location decisions. An explicit elaboration of the data collection process and review method is available in the appendix.

The selected empirical approach is not without its limits, especially regarding the relationship between decision-making events and retrospective accounts of industrial location policy as their outcome. Although the connection between institutional logics and organizational decision-making is assumed in theory (Thornton \& Ocasio 2008), the analysis of retrospective publications provide only directive insights on the specific role that the identified logics employed in directing the actions and perceptions of responsible decision-makers and shaping the outcomes of actual decision-making events. Establishing specific links between different 
organizational interests within the Soviet bureaucracy and advocated institutional logics would require substantial efforts in tracking and cross-examining archival documentation of these events over the course of multiple decades, which exceeds the scope of this article and might still fall short of reaching conclusive statements about the intensions and rationales of the decision-makers. As a result, the presented conclusions regarding the role of logics in guiding the decision-making and execution of Soviet industrial location strategy should be treated as indicative and interpretative generalizations of manifestations over a long-term period, offering only a limited perspective to specific location decisions or to the institutional environment surrounding them. The results, however, present rich possibilities for hypothesis-testing in micro-level case studies of decision-making events and their contextual environments.

\section{Military logic}

Military logic was based on the core idea that industries and their location were subordinate to the demands of national defense considerations and the improvement of the country's military capabilities. The purpose of industrial location policy was to secure essential requirements of army mobilization and supply logistics while ensuring that possible foreign invasions would not disturb industrial operations (Rodgers 1974; Davies 1998). This stream of thought had been imprinted on Russian industrial policies ever since Peter the Great's reign in the early 18th century. In the 19th century, the construction of a railroad network, especially the TransSiberian railroad in the 1890s, and the development of textile, metal and petro-coal industries were central to Tsarist economic strategy (Von Laue 1953; Gatrell 1982). The role of military importance was high: Nicholas II's financial minister Sergey Witte used to complain that railroad allocation was not optimal for economic development because the rail network had been planned by military generals (Von Laue 1951, 187; 1953, 439). Between the two world wars, achieving military strength was the most immediate objective of the Soviet industrialization effort (Nove 1969).

Military logic was reinforced by the growing likelihood of war in Europe, which directed industrial location policy further towards the eastern peripheral regions (Rodgers 1974; Bradshaw 1991). Siberia's secretive remoteness and the planners' concept of a closed economy increased the appeal of this logic in location policy (Mellor 1982). The autarky of regions was in part encouraged by military logic. Still in the 1950s, the self-generating growth of the far eastern regions was considered important in order to discourage China's aggression and encourage Japan politically (Hooson 1972). Pledges to invest in far eastern regions were 
repeatedly renewed in official statements with little considerations of the high costs and low turnover compared to European regions (Hooson 1972).

World War II and its aftermath cemented the position of military logic in industrial location policy. During the war, many industrial plants and their workers located in the Western regions were evacuated to the eastern regions, leading to emergence of strong concentrations in the Volga-Ural and Baikal regions (Rodgers 1974; Mellor 1982). Earlier investments in the eastern regions could also be justified due to experiences of the German invasion, giving the military logic further impetus to influence post-war location policies (Mellor 1982). The strong political position of the victorious Red Army along with the intensifying Cold War ensured that strategic viewpoints of military logic remained critical in Soviet location decisions (Chernyavskiy 1967, 60; Hooson 1972; Davies 1998).

With the exception of the concept of self-sufficiency, argumentation based on military logic, such as the emphasis on mobilization efficiency, were mostly omitted from printed discussions in Soviet economic-geographical journals during the 1930s (Samuelson 2011, 128-129). Scattered observations noting the importance of defensive capabilities in location decisions appeared after World War II, but mostly the role played by military logic in Soviet planning has been reconstructed from economic geographical analyses appearing in Western journals.

\section{Economic logic}

The economic logic bound together various arguments, representing a formal type of rationality (Kalberg 1980,1158-1159) from the perspective of economic profitability. This logic included arguments stating the need to locate industrial enterprises according to economic utility and to minimize costs of production and transport within the limits of the socialist economic system. Economic logic has also directed occasional reorganizations of changes in investment allocations according to signals of shortage and imbalances (Kornai 1992, 164).

The objectives of Soviet planning organizations were based on economic optimization and maximizing the output of productive forces ever since they were established in the early 1920s (Lonsdale 1961). During that time, Russian and Soviet economic geographers were introduced to Alfred Weber's (1909) ${ }^{\mathrm{ii}}$ theory of industrial location which, alongside Lenin's fascination with Taylorism (Maier 1970; Sochor 1981), provided scientific argumentation for economic logic and improved its priority claim during the 1920s and 1930s (Rodgers 1974). In 1918, Vladimir Lenin had acknowledged the importance of economic logic, when decreeing that 
industrial distribution should derive from proximity to raw materials, in order to minimize the costs of transportation between the site of production and local markets (Lenin 1918). The proclaimed goals of regionalization closely followed contemporary economic logic: good interregional transport connections, the calculation of the most suitable natural conditions and energy resources for industrial specialization, and the maximization of labor efficiency under an integrated economic system (Lonsdale 1965, 467 - 468; Saushkin 1966, 6; Nekrasov 1966). The Soviet discourse, significantly influenced by works of Nikolay Baransky ${ }^{\text {iii }}$ and Nikolay Kolosovsky, ${ }^{\text {iv }}$ preserved and invoked the concept of economic regionalization throughout its existence, implying that the regional model-based GOELRO followed the objective of formal economic rationalization. Particularly, the attention paid to the potential of uncharted energy resources in industrial location decisions (e.g. Nekrasov 1964) recounted the doctrinal narrative behind the GOELRO program.

The reaction to Weberian location theory created a distinct contradiction between economic logic and socialist institutional framework. Weberian theory asserted that the optimal industrial location is determined by the optimization of the costs of transporting resources to the location of production and the costs of transporting commodities from the production location to the markets. The calculation of these costs also enabled the situation when a firm would relocate to optimize its production function to be determined. However, Weber's model was based on a market environment, which was interpreted to be incompatible with the socialist economic model (Saushkin 1966). Official Soviet rhetoric renounced the Weberian perspective as a bourgeois influence (Feygin 1958; Lonsdale 1961; Probst 1965) despite its implicit influence on economic geography via economic logic (Lonsdale 1961, 13; 1965; Saushkin 1961; Huzinec 1977). Growth orientation in location principles revealed that Weberian thinking was gradually reintroduced in planning methodology (Rodgers 1974) in the 1960s. For example, Nikolay Baransky's (1956) textbook approach was predominantly Weberian.

An internal debate emerged within the economic logic concerning the costs of transportation and the exploitation of local natural resources. Regarding industrial locations, the question was essentially whether to locate more industrial plants to peripheral regions in the east due to the seemingly limitless potential of unutilized natural resources or to continue to develop existing and technologically advanced industrial districts in the western part of Russia (Rodgers 1974; Shaw 1991). Despite opposite alternatives to industrial location planning, the reasoning behind both approaches relied on contemporary economic logic. The eastern regions promised rich deposits of raw materials to fuel industrial expansion, while investments in the western regions 
were economically sound due to the proximity of markets and an established transportation network (Davies 1956; Rodgers 1974). Another contradictory form of economic logic was the growth of plant size-so-called giantism (gigantomania) which started as an established practice during the first five-year plan (1928-1933) and was officially abandoned in 1936, only to surface once again in the 1950s (Katz 1977; Taaffe 1980, 157). Giantism manifested itself in exceptionally large plant sizes in heavy industry, intended to boost agglomeration economies and scales of production to unparalleled levels (Katz 1977). Leon Smolinski (1962) saw the essence of giantism as a misinterpreted Marxist doctrine of centralized increase in the scale of production. According to him, the original Marxist idea characterized industrial processes from a historical perspective, rather than offering operational guidelines for industrial organization, as Soviet planners interpreted them (Smolinski 1962, 140). Yet the preference for large-scale production units in Russia did not originate solely in Soviet ideology. According to Katz (1977, 211), the preference for large factories was already present in Tsarist times, with 41.4 percent of the industrial labor force employed in factories with more than 1,000 workers. Further reasons for giantism were embedded in the institutional mechanisms of central planning that favor large-scale operations (e.g. Eucken \& Hutchinson 1948) and the drive to surpass the efficiency of large establishments in the United States (Smolinski 1962, 141). Kornai (1992) argued that giantism was partly supported by bureaucratic logic. Although Smolinski considered the giantist projects of the 1930s failures in their own times due to high transport costs and various shortfalls and delays during their formation, he admitted that over long-term development these projects appeared more feasible and found more justification for the increased size of production units in the 1960s (Smolinski 1962, 146). After giantism and eastern development sharply increased transport costs, Soviet planners grew more conscious of their minimization, which also supported the idea of regional self-sufficiency from the perspective of economic logic (Lonsdale 1961).

\section{Regional logic}

The core tenets of regional logic emerged from the idea of equal industrial distribution between regions, which was included in the Marxist-Leninist program during the early 1920s. Regionally balanced industrialization was thought to decrease social and economic inequality within the country (Rodgers 1974; Liebowitz 1991), promote economic growth in diverse industrial sectors and regions and develop peripheral areas which remained largely nonindustrialized (Baransky 1956; Mellor 1982). In many ways, the argumentation of regional logic employed a theoretical type of rationality (Kalberg 1980, 1152-1155), grounding its 
central beliefs in the Marxist doctrine of social equality. For example, the discursive concept of the territorial division of labor included in itself a theoretical assumption that a regional dimension was a necessary component of the ideal organization of a national economy. However, frequent discussions in Soviet economic geographical journals (e.g. Planovoye Khozyaystvo) of the complex development of territorial production and regionalization did not automatically invoke regional logic, since coordination of economic production at the regional and sectoral level was also guided by economic logic. The concepts of territorial-production complex and regionalization utilized regional logic as a premise for their legitimation, but not as a concrete argument that should direct economic-geographical operations. Regional logic was also politically invoked to attract support from minority nationalities during the early Soviet period, when the establishment of the Soviet system was still incomplete (Rodgers 1974).

The GOELRO program was one of the first and most essential industrial goals for the Bolsheviks and a crucial tool for the establishment of centralized control and development of regions. GOELRO was strongly associated with regional logic and was considered a means of increasing economic and political interrelatedness and connections between regions while retaining administrative control in the hands of central leadership. Consequent mutual dependence and regional specialization was supposed to benefit industrial growth, integrate interregional planning and boost equality between regions (Saushkin 1962, 29-30; Lonsdale 1965).

At the turn of the 1930s, regionally equality in location policy was also seen as a way to increase the self-sufficiency and interconnectedness of regions (Lonsdale 1965; Mellor 1982; Shaw 1991). The concept of self-sufficiency also drew support from local needs. For example, a decree in the 18th Party Congress outlined that the manufacturing of foodstuffs, such as dairy and meat products, flour and beer, must take place in sufficient quantities in each republic, territory and region (Baransky 1956). When regionally autarkic production faced difficulties due to needs for, for example, highly specialized branches of industry such as chemistry, regions participated in interchange with each other (Mellor 1982). The interconnectedness of regions and urban areas also served as a way to even out the size of cities (Nekrasov 1964; Mikhailov \& Solovyev 1965). At the enterprise level, interconnectedness through informal horizontal relations became an important, though not explicitly admitted, function of the Soviet economy alongside central planning (Davies 1998). 
Despite its fundamental role in official statements, the effective influence of regional logic was not substantial during the late Stalinist era between 1940 and 1955 (Rodgers 1974). This did not, however, prevent Soviet economic geographers from including elements of regional logic into theoretical models, and the emphasis on regional logic in Soviet location theory increased in the 1960s. For example, Alexey Lavrishchev $(1969,9)$ argued that distribution and location of enterprises was based on the so-called balanced method, which was principally based on the estimations of production and consumption balances between regions and secondarily on regional specialization, agglomeration and Weberian cost calculations. During the late 1950s and 1960s, development in economic cybernetics further boosted the interest in decentralizing planning system and optimizing production according to regional specialization (Grossman 1962; Peters 2016). Lavrishchev $(1969,15)$ devoted considerable attention to the role of technological progress in economic geography, noting that the industrial development of several Soviet regions depended on scientific production methods and technological apparatus. Huzinec $(1977,263)$ notes that the use of such technologies and mathematical models were slowly introduced to Soviet planning in the 1970s, though on a limited scale.

Finally, regional logic also gave impetus for vertical bargaining and local patriotism in different Soviet republics throughout the Soviet era. Regional officials sought to maintain their political power and prestige by demanding industrial investments on an equal scale compared to other regions (Kornai 1992). When giantism generated self-reinforcing development towards further large-scale projects, each region and republic pleaded for the launching of new projects in their own area (Smolinski 1962). Despite these appeals, regionally grounded location policies after the Stalinist era were enacted mostly in the distant regions of the Russian republic, rather than in other Soviet republics (Hooson 1972). This has been criticized as possible Great Russian chauvinism (Hooson 1972), which was starkly in contrast to the ideological goals embedded in regional logic.

\section{Dynamics of institutional logics - competition and coexistence}

Although contended institutional fields often tend to settle on a dominant logic (Reay \& Hinings 2005), the environment for Soviet industrial location sustained multiple logics for prolonged periods of time. During the early period of industrialization, when the institutional field of industrial location policy was developing, the conflict of logics emerged in different ways to interpret and rationalize (Kalberg 1980) location problems. Once the logics and their competitive positions had become established, the forms of coexistence stabilized. When the 
balance of power shifted between institutional logics at the societal level, they altered the form of interactions and the coexistence of logics at the organizational level of industrial location policy.

As described earlier, the literature has identified three modes for simultaneously existing logics and how the competing logics operate on the organizational level: (1) a rivalry managed by a series of battle encounters, (2) informal covert influencing to achieve dominance, and (3) coexistence through collaborative mechanisms. An analysis of Soviet industrial location policy between the 1920s and 1960s strongly suggests that these were also the forms in which the presented institutional logics coexisted, as exemplified below. This would imply that specific industrial location decisions resembled constellations (Goodrick \& Reay 2011), which reflected temporary and prevailing hierarchies of logics and their coexistence.

First, confrontational encounters between logics aroused intensive, battle-like debates among Soviet economic geographers in the late 1920s and early 1930s. The issue of conflict concerned industrial location decisions to expand heavy industry in the Siberian regions, spearheaded by the establishment of the Ural-Kuznetsk Combine (UKC) as the flagship of the first five-year plan. This particular debate was exceedingly important for proponents of each logic, because the ultimate stance of the Communist leaders to the question determined the direction of Soviet industrialization for years to come. In 1926, negotiations between the officials from GOSPLAN, VSNKH and the Central Committee of the Communist Party led to a decision to build a new large-scale metallurgical complex in the Urals rather than to boost the established complex in Donbass (Holzman 1957). The Metallurgical Division of the Ukrainian Planning Commission and the Commissariat of Railroad Transport opposed the development of the $\mathrm{UKC}$, invoking the economic logic that transport costs of interconnected production between Kuzbass and Magnitogorsk were too high for local or all-Siberian demand. Even if the scale of operations would be large enough for economical production, the consumption would have to be projected to the European part of Russia, which would increase the length of transport to markets and total costs. Another opposing argument of railroad officials questioned the UKC plan on the grounds that consequent railroad construction did not meet the contemporary needs of the Siberian region, which should have been geared towards agricultural, not industrial, development (Holzman 1957, 375-376). However, the military logic ultimately prevailed and the 15th Communist Party Congress in 1927 adopted a policy to concentrate the metallurgical and arms industries in the Urals. The goal was not only to protect key industries from invasions from the west, but also from the east - as Japan might participate in a coalition of foreign 
powers (Samuelson 2011, 41-43). ${ }^{\mathrm{v}}$ This policy was also in line with regional logic: UKC's key location would enable further industrialization in the eastern regions and thus even out the distribution of industry across the Soviet Union. Already in the early 1920s, the governmental electrification commission GOELRO had realized the difficulties that the vast distances and minor population centers in Siberia presented for energy distribution and foresaw the need for a large industrial center in the Ural region (Holzman 1957, 373-374). Finally, the propaganda value of building a gigantic industrial complex from scratch in Magnitogorsk made the UKC an attractive industrial experiment for Soviet leadership (Kotkin 1997, 38). The outcome of this discussion repeated during the 1930s, resulting in the establishment of, among others, an industrial district in Chelyabinsk (Samuelson 2011), and reflecting the acquired dominance of military logic. The experiences of invasion during World War II influenced allocation strategies after the death of Stalin. Despite efforts in the 1930s to industrialize eastern regions based on military logic, the invading Germans were able to occupy territories containing $20 \%$ of the Soviet industrial capacity (Davies 1998, 59; Harrison 1998, 252-254). Hooson (1972) and Dienes (1972) observed that after World War II, strategic priorities continued to clash with economic considerations in industrial planning and allocation. For example, in the fuel and energy industries the focus of allocation turned to western Siberian regions from Donbass and Baku, which accounted for two-thirds of energy supply in 1941 and had been occupied during the war. Confrontations and divided opinions over the distribution and transfer of energy hampered the projects, making it hard for planners to decide whether to promote long-distance transmissions lines from far-away regions where large complexes operated or to favor local energy sources and electricity grids (Dienes 1972, 447; Hooson 1972, 543-544). The attempts to pursue economically sound investments in industrial districts in European Russia repeatedly faced political pressure from the supporters of regional and military logics, which gained leverage due to deteriorating diplomatic relations with China (Hooson 1972, 554).

Second, throughout most of the 1920s and 1960s the rivalry between regional and economic logics can be described as an unresolved conflict or "uneasy truce" (Goodrick \& Reay 2011, 377). Neither logic could establish a constant dominant position over the other, since both regional equalization and economic progress remained set objectives of the Communist Party. Vertical bargaining between central planners and regional producers became intrinsic phenomena (Kornai 1992), reflecting not only the hierarchical struggles or incentives of different parties in an economic sense, but also the ongoing clash of separate logics. Soviet economic geographers attempted to consolidate the situation. For example, Nikolai Baransky 
highlighted economies of scale in pursuing large construction projects in the peripheries as well as benefits of agglomeration in transportation, while simultaneously underlining Siberian industrialization as a way to even out social and economic equality (Baransky 1956, 17, 40, 46, 57). The instability of what logic dominated led Western observers to discuss what the prioritization of location principles was. In particular, the question of whether military considerations had been indisputable priorities was frequently discussed in Soviet studies journals throughout the 1970s (see Koropeckyj 1967; Abouchar 1973; Davies 1974). Contrary to Holzman (1957) and Lonsdale (1961), Koropeckyj saw military priorities as the most important principle to which the two others were subordinated, with economic principles taking priority over regional ones (Koropeckyj 1965, 61, 64-65). The conflict between regional and economic logics continued throughout the Soviet period and has maintained its role in the postSoviet debates as well (Kinossian 2013, 615-618).

Third, pragmatic collaboration of logics became possible after World War II, once the basic location principles and field-level logics had become established. In most cases, two logics with integrated goals were able to achieve dominance in location policy. In these cases, the third logic was either overlooked or indifferent to locational outcomes. Combinations of the military and economic logics existed within the military-industrial complex, where production efficiency was beneficial from an economic and military perspective (Barber et al. 1999). The promotion of regional self-sufficiency and interconnections, especially in locating industries to eastern regions satisfied the needs of both regional and military logics (Lonsdale 1965; Mellor 1982; Shaw 1991). In turn, a synthesis of economic and regional logics led to the formation and regionally balanced distribution of territorial-production complexes (TPC) (Kolosovskiy 1969; Lavrishchev 1969) and the increasing of auxiliary industrial branches in urban agglomerations (Cheremisin 1966). Although military logic was not the primus motor in the planning of TPCs, its status was not endangered by such regional organization. This congruence of aims might partly explain the intensive efforts of several economic geographers to promote TPC-based regional organization as the template for the Soviet industrial economy from the 1960s onwards.

\section{Impact of competing logics on Soviet institutional environment}

An analysis of Soviet industrial location policy as an outcome of competing institutional logics underlines two pivotal questions: How did the competition of logics affect Soviet industrial 
location policy? Why was the configuration of multiple logics able to survive without convergence towards a dominant logic?

First, the most important implication is that the competition of institutional logics and the shifting status of dominance created strategic discontinuities and disruptions to economic geographical planning. Each logic was able to survive indefinitely, becoming deeply embedded in the Soviet organization. The impact of logics on industrial location decisions was particularly direct because of the vertical hierarchy of Soviet bureaucracy. According to Kornai (1992, 41, 118-130), the primary incentive of bureaucratic decision-makers was to obey or support the views of superiors, not to find the best possible solutions for economic problems. Thus, any shift of dominance between logics at the top level was reflected in locational policies, even if the subordinate levels held on to a different logic. Alternatively, in the absence of a dominant logic at the superior level, different logics at the subordinate level could achieve dominant status. The resulting picture helps to explain why locational decision-making contained inconsistencies and the results deviated from originally designated plans. From a long-term perspective, the outcomes of industrial location policy represented unsolved conflicts within Soviet organizational and bureaucratic entities. An additional difficulty arouse from the intrinsic path-dependence of industrial geography (Martin \& Sunley 2006). It was difficult to make optimal location decisions to solve the problems of the regional economic system because the transport network, urban concentrations and industrial interdependencies had developed according to earlier location decisions. A similar path-dependence governed industrial production, because inconsistent decision-making created shortages of nonprioritized products (Kornai 1992, 176-177), but in the case of economic geography, the accumulated sunk costs (Clark \& Wrigley 1995) prevented significant reversal of adopted locational strategy (Hooson 1972, 553). The industrialization of the Siberian regions, the most pressing issue in the criticism of Hill and Gaddy (2003), is a prime example of this process. The transformation of development in the east from an ambitious venture into irreversible misdirection encapsulates the harmful impact of competing logics, which not only contributed to suboptimal location strategies, but also complicated retreat from the chosen course of strategy due to vested interests, when the expectations began to falter. In this way, the prolonged simultaneous existence of logics and their consequent competition was connected to lock-in and structural inertia in Soviet economic geography. In the 1960s and 1970s, pressures to reform industrial geography and development of international economic competition posed formidable challenges for the Soviet economy. Rival Western nations were capable of 
maintaining a steady rate of technological progress, upholding economic growth through innovations and transforming their industrial geography with market mechanisms. Meanwhile, Soviet industry was reluctant and even incapable of transforming its industrial structure or geography to meet the demands of such economic model (Davies 1998, 79-80). The proclaimed military rivalry with the United States and consequent huge state investments in the arms industry further complicated full-scale reforms of the Soviet industry model.

If the competition of multiple logics produced suboptimal results, then why was there no emergence of a dominant logic and how to explain the survival of multiple logics for prolonged periods of time? One possible explanation is that the evaluation of performance was dependent on embedded institutional logics. This interpretation touched on Kornai's (1992) view of bureaucratic performance logic, which preferred hierarchical and institutional stability over economic profit. Similarly, Lounsbury (2007) has shown that performance evaluations of American money management firms varied because of competing logics. Hence, it would be possible to conclude that different performance indicators both maintained the unsettled rivalry of logics and resulted in an adverse form of industrial location policy, at least when viewed in hindsight.

However, another key factor was that the planners and decision-makers were bound rationally regarding the results of decisions, causing the survival of logics and their inability to reach lasting dominance. Industrial location decisions were made with long-term expectation (Hill \& Gaddy 2003, 91) and their success remained unpredictable for equally long periods. For example, Holzman (1957) thought that the development of the Siberian regions might eventually lower the transport costs to profitable levels, at least if examined in light of the other objectives of Soviet planners or in the anticipation of consequent markets (Lonsdale 1961, 14). A similar concession was made by Katz (1977, 219), concerning the time preference of giantism: only over a very long period could the policy possibly overcome its negative strains. Koropeckyj $(1965,68)$ questioned Holzman's view that large-scale industrial projects, such as UKC, might prove to be economically more profitable investments in the long run. He argued that expansions of western industrial centers, such as Donbass, would have enjoyed higher profits in the short run, which could have then been re-invested to boost profits in the long run as well. The purpose of directing investments in heavy industry to the eastern regions was, according to Koropeckyj, part of a long-term plan to create a strong arms industry that, once developed in due course, would integrate raw material resources with the machine-building industry. This strategy seemed perfectly rational at the time when the UKC was established, 
but political developments and Hitler's rise to power in 1933 disturbed the realization of the original plan and redirected industrial investments to centers in European Russia in the late 1930s (Koropeckyj 1965, 70-72). After the country's victory in the Second World War, the state of the Soviet economy hardly showed signs of irreversible strategic failure. In the 1960s, short-term struggles to meet the expectations of economic development and coordination problems in production were visible, but eventual long-term outcomes of location policy remained unclear and thus no logic could be outrightly proclaimed as adverse. Although the competition of logics presumably disrupted consistent locational strategies, accumulating difficulties in the spatial industrial structure and the real scale of economic problems became apparent only closer to the end of the Soviet Union (Bradshaw \& Connolly 2016, 711).

\section{Discussion}

The objective of this study was to utilize a theoretically oriented approach to understand the mechanisms and processes behind Soviet industrial location policies. The article contributes to extant literature by proposing a link between Soviet industrial location policies and underlying institutional logics. The results of the analysis highlight the disruptive effect that competing institutional logics had on Soviet locational strategies. For Soviet leaders, addressing the problems created by structural inertia and inconsistent planning strategies would have required the management of competing institutional logics. There were, however, structural, institutional and ideological factors which maintained the existence of multiple logics and forestalled convergence towards one dominant logic. Bounded rationality and the complexity of path-dependent outcomes made it increasingly difficult to refute claims of rival logics.

The results re-conceptualize prior accounts of industrial location principles with up-to-date organizational institutionalist literature. These principles not only resonate with the institutional logic perspective, but the modes of interaction and the competition of these logics match the forms of simultaneous existence that has been observed in other studies and different institutional contexts (Reay \& Hinings 2009; Goodrick \& Reay 2011). By demonstrating such correspondence, the study encourages more theoretically oriented analyses of Soviet society and its organizational history. Meanwhile, the article addresses the call for historically oriented studies of institutional logics, their contingency and influence on organizational strategy (Thornton et al. 2012, 13, 182-183) as well as origins, structure and role in decision-making (Lounsbury 2007, 303). 
It must be emphasized that the results of this study should not be directly extended to the postSoviet era. However, the path dependence argument and the observation that the analyzed framework parallels the manifestations of competing logics in other environments suggest a link to the study of the post-Soviet environment. In recent years, similar settings of competing logics have been identified in Russian regional planning (e.g. Kinossian 2013), with similar consequences of inconsistent policies and stagnant development. An important topic for further study would be to examine the source of these logics in the contemporary context. It should be considered if the competition and coexistence of logics are recurring due to the persistence and historical imprinting of certain elements in the Russian institutional environment or if they stem from other sources in the post-Soviet inter-institutional system.

\footnotetext{
${ }^{\mathrm{i}}$ Gosudarstvennaya Komissiya po Elektrifikazii Rossii (State Commission for the Electrification of Russia) ii Alfred Weber's main work, Theory of the Location of Industries, was translated into Russian in the 1920s and reportedly received large attention (Friedrich 1969, xxix).

iii Nikolay Baransky (1881-1963) worked in the VSNKh hiii in 1919-1920 and founded the officially supported Regional School approach in Soviet economic geography, while also setting up the chair of economic geography in Moscow State University (MGU). Baransky authored and supervised numerous publications and textbooks, including his major textbook Economic Geography of the U.S.S.R. (1956).

iv Nikolay Kolosovsky (1891-1954) took part in the GOELRO project and worked as the director of East Siberian and Far East sector in GOSPLAN from 1920 to 1925. He also participated actively in the buildup of the First Five Year Plan in 1928-29 and was put in charge of the UKC organization commission in 1930. After the Second World War, he was appointed to professorship in MGU where he worked until his death in 1954 (Kazanskiy, Kalashnikov and Saushkin 1969). Kolosovsky contributed significantly to conceptual development of territorial-production complexes (territorial'no-proizvoditel'nyj kompleks). His ideas emphasized the importance of interdependence between economic regions and natural and economic conditions of local geography in order to determine distribution of production in socialist system (Kolosovsky 1969). v Although the Ural development policies were repeatedly highlighted in official plans, the actual state demand for raw materials, products and machinery also led to the simultaneous strengthening and expansion of older industrial districts in Leningrad and Donbass in the 1930s (see Samuelson 2011, 43).
} 


\section{References}

Abouchar, Alan. 1973. Inefficiency and reform in the Soviet economy. Soviet Studies 25: 66-76.

Acemoglu, Daron, and James A. Robinson. 2013. Why nations fail: The origins of power, prosperity, and poverty. Broadway Business.

Amann, Ronald, and Julian Cooper. 1982. Industrial innovation in the Soviet Union. Yale University Press.

Autio-Sarasmo, Sari. 2016. Technological modernisation in the Soviet Union and post-soviet Russia: Practices and continuities. Europe-Asia Studies 68 (1): 79-96.

Baransky, N.N. 1956. Economic geography of the U.S.S.R. Moscow: Foreign Language Publishing House.

Barber, John \& Harrison, Mark \& Simonov, Nikolai \& Starkov, Boris. 1999. "The structure and development of the defence-industry complex". In The Soviet defence industry complex from Stalin to Khrutschev, edited by Barber, J. and Mark Harrison, 3-33. New York: St. Martin's Press, Inc.

Bradshaw, Michael. 1991. "Introduction: Industrial restructuring and Soviet regional development". In The Soviet Union: A new regional geography?, edited by Michael Bradshaw, 3-14. London: Belhaven Press.

Bradshaw, Michael, and Richard Connolly. 2016. Russia's natural resources in the world economy: History, review and reassessment. Eurasian Geography and Economics 57 (6): 700-26.

Clark, Gordon L., and Neil Wrigley. 1995. Sunk costs: A framework for economic geography. Transactions of the Institute of British Geographers: 204-23.

Davies, R.W., 1956. Reports and commentaries: The reappraisal of industry. Soviet Studies, 7 (3): 308 $-331$.

1974. A note on defence aspects of the Ural-Kuznetsk combine. Soviet Studies 26 (2): 272-3.

1998. Soviet economic development from Lenin to Khrushchev. Vol. 34 Cambridge University Press.

Dellenbrant, Jan Åke. 1986. The Soviet regional dilemma: Planning, people, and natural resources. New York \& London: M.E. Sharpe, Inc.

Dienes, Leslie. 1972. Investment priorities in Soviet regions. Annals of the Association of American Geographers 62 (3): 437-54.

1983. "Regional economic development". In The Soviet economy: Toward the year 2000, edited by Bergson \& Levine, 218-269. London: George Allen \& Unwin.

Ericson, Richard E. 1991. The classical Soviet-type economy: Nature of the system and implications for reform. Journal of Economic Perspectives 5 (4): 11-27. 
Eucken, Walter, and T.W. Hutchison. 1948. On the theory of the centrally administered economy: An analysis of the German experiment. part I. Economica 15 (58): 79-100.

Feygin, Ya. G. 1958. Razmeschenie proizvodstva pri kapitalizme i socializme. Moscow: Gospollit.

Friedland, Roger and Robert A. Alford. 1991. "Bringing society bcack in: Symbols, practices, and institutional contradictions". In The new institutionalism in organizational analysis, edited by Powell, Walter W. and Paul J. DiMaggio, 232-263, Chicago: University of Chicago Press.

Friedland, Roger. 2012. Book review: The Institutional logics Perspective: A new approach to culture, Structure, and Process. (Patricia H. Thornton, William Ocasio \& Michael Lounsbury).M@n@gement 5, 583-595.

Friedrich, Carl. 1969. "Editor's introduction". In Alfred Weber's theory of the location of industries, edited by Friedrich, C, xiii-xxxiii. Chicago \& London: Chicago University Press.

Gatrell, Peter. 1982. Industrial expansion in tsarist Russia, 1908-14. The Economic History Review 35 (1): 99-110.

Goodrick, Elizabeth and Trish Reay. 2011. Constellations of institutional logics: Changes in the professional work of pharmacists. Work and Occupation 38 (3): 372-416.

Greve, Henrich and Zhang, Cyndi Man. 2017. Institutional logics and power sources: Merger and acquisition decisions. The Academy of Management Journal 60 (2): 671-694.

Grossman, Gregory. 1962. The structure and organization of the Soviet economy. Slavic Review 21 (2): 203-22.

Harrison, Mark. 1998. “The Soviet Union: The defeated victor”. In The Economics of the World War II, edited by Harrison, Mark, 268-301. Cambridge: Cambridge University Press.

Hill, Fiona, and Clifford G. Gaddy. 2003. The Siberian curse: How communist planners left Russia out in the cold. Brookings Institution Press.

Hoeffding, Oleg. 1959. The Soviet industrial reorganization of 1957. The American Economic Review 49 (2): 65-77.

Holzman, Franklyn D. 1957. The Soviet Ural-Kuznetsk combine: A study in investment criteria and industrialization policies. The Quarterly Journal of Economics 71 (3): 368-405.

Hooson, David. 1972. The outlook for regional development in the Soviet Union. Slavic Review 31 (3): 535-54.

Huzinec, George A. 1977. A reexamination of Soviet industrial location theory. The Professional Geographer 29 (3): 259-65.

Kalberg, Stephen. 1980. Max Weber's types of rationality: Cornerstones for the analysis of rationalization processes in history. American Journal of Sociology 85 (5): 1145-1179. 
Katz, Barbara G. 1977. "Giantism" as an unbalanced growth strategy: An econometric investigation of the soviet experience, 1928-40 Soviet Union/Union Soviétique 4 (1): 205-22.

Kazanskij, N.N., Kalashnikov, T.M., and Saushkin, Yu. G. 1969. 'Predislovie'. In Kolosovsky, Nikolay: Teoriya ekonomicheskogo rayonirovaniya, edited by Kazanskiy, Kalashnikov, and Saushkin, 3-13. Moscow: Izdatel'stvo Mysl'.

Kinossian, Nadir. 2013. Stuck in transition: Russian regional planning policy between spatial polarization and equalization. Eurasian Geography and Economics 54 (5-6): 611-29.

Kofanov, D.A. and T.I. Mikhailova. 2015. Geograficheskaya koncentraciya sovetskoy promyshlennosti: Sravnitel'nyiy analiz. Zhurnal novoy ékonomicheskoy associacii 4 (28): 112-141.

Kolosovsky, N.N. 1969. Teoriya ekonomicheskogo rayonirovaniya. Moscow: Izdatel'stvo Mysl'.

Kornai, János. 1992. The socialist system: The political economy of socialism. Princeton, NJ: Princeton University Press.

Koropeckyj, I.S. 1965. Location problems in Soviet industry before World War II: The case of Ukraine. Chapel Hill: The University of North Carolina Press.

1967. The development of Soviet location theory before the Second World. Europe-Asia Studies 19 (1): 1-28.

Kotkin, Stephen. 1997. Magnetic mountain: Stalinism as a civilization. Berkeley, London \& Los Angeles: University of California Press.

Krugman, Paul. 1991. History and industry location: The case of the manufacturing belt. The American Economic Review 81 (2): 80-3.

Kumo, Kazuhiro. 2004. Soviet industrial location: A re-examination. Europe-Asia Studies 56 (4): $595-$ 613.

Lamberg, Juha-Antti, Arjo Laukia, and Jari Ojala. 2014. The anatomy and causal structure of a corporate myth: Nokia by the book. Management \& Organizational History 9 (3): 235-55.

Lavrishchev, A.N. 1969. Economic geography of the USSR. Moscow: Progress Publishers.

Lenin, V.I. 1918. "Draft Plan of Scientific and Technical Work". In Lenin's Collected Works, $4^{\text {th }}$ English Edition, edited by Daglish, 314-317. Moscow: Progress Publishers. https://www.marxists.org/archive/lenin/works/1918/apr/x03.htm

Liebowitz, Ronald D. 1991. Spatial inequality under Gorbachev. The Soviet Union: A New Regional Geography: 17-37.

Lonsdale, Richard E. 1965. The Soviet concept of the territorial-production complex. Slavic Review 24 (3): 466-78. 
1961. Industrial location planning in the Soviet Union. The Professional Geographer 13 (6): 11-5.

Lounsbury, Michael. 2002. Institutional transformation and status mobility: The professionalization of the field of finance. The Academy of Management Journal 45 (1): 255-266.

2007. A tale of two cities: Competing logics and practice variation in the professionalizing of mutual funds. The Academy of Management Journal 50 (2): 289-307.

Maier, Charles S. 1970. Between taylorism and technocracy: European ideologies and the vision of industrial productivity in the 1920s. Journal of Contemporary History 5 (2): 27-61.

Markevich, Andrei, and Mihailova, Tatjana. 2013. "Economic geography of Russia". In The Oxford Handbook of Russian Economy, edited by Alexeev, M \& Weber, S., 617-643. Oxford: Oxford University Press.

Martin, Ron, and Peter Sunley. 2006. Path dependence and regional economic evolution. Journal of Economic Geography 6 (4): 395-437.

Mellor, Roy. 1982. The Soviet Union and its geographical problems. London and Basingstoke: Macmillan Press Ltd.

Mikhailov, S. and N. Solovyev 1965. Malye isrednie goroda i razmeschenie promyshlennosti SSSR. Planovoye Khozyaystvo 1: 24-32.

Nekrasov, N. 1964. Nekotorye problemy razmescheniya promyslennosti. Planovoye Khozyaystvo 8: 615.

1966. Nauchnie osnovy razmescheniya proizvodstvennyh sil pri socialism. Planovoye Khozyaystvo 2: 78-87.

Nove, Alec. 1969. An economic history of the U.S.S.R. Allen Lane: The Penguin Press.

1986. The Soviet economic system. Boston, MA: Allen and Unwin.

Owen, Thomas C. 1995. Russian corporate capitalism from Peter the Great to perestroika. New York: Oxford University Press.

Peters, Benjamin. 2016. How not to network a nation: The uneasy history of the Soviet internet. Boston, MA: MIT Press.

Probst, Abram. 1965. Effektivnost' territorial'noy organizacii proizvodstva. Moscow: Mysl'.

Purdy, Jill M. and Barbara Gray. 2009. Conflicting logics, mechanisms of diffusion, and multilevel dynamics in emerging institutional fields. The Academy of Management Journal 52 (2): 355-380.

Reay, Trish and C.R. Hinings. 2005. The recomposition of an organizational field: Health care in Alberta. Organization studies 26 (3): 351-384. 
2009. Managing the rivalry of competing institutional logics. Organization Studies 30: 629652.

Rodgers, Allan. 1974. The locational dynamics of Soviet industry. Annals of the Association of American Geographers 64 (2): 226-40.

Samuelson, Lennart. 2011. Tankograd: The formation of a Soviet company town: Cheljabinsk, 1900s1950s. UK: Palgrave Macmillan.

Saushkin, Yulian G. 1962. Economic geography in the USSR. Economic Geography 38 (1): 28-37.

1961. The construction of economic models of regional and local territorial-production complexes. Soviet Geography 2 (4): 60-6.

1966. A history of Soviet economic geography. Soviet Geography 7 (8): 3-98.

Scott, Richard W. 2008. Institutions and organizations: Ideas and interests. Los Angeles: Sage.

Shaw, D.J.B. 1991. Restructuring the Soviet city. The Soviet Union: A New Regional Geography: 6782.

Smolinski, Leon. 1962. The scale of Soviet industrial establishments. The American Economic Review: 138-48.

Sochor, Zenovia A. 1981. Soviet taylorism revisited. Soviet Studies 33 (2): 246-64.

Spulber, Nicolas. 2003. Russia's economic transition from late tsarism to the new millenium. Cambridge: Cambridge University Press.

Strang, David and John W. Meyer. 1993. Institutional conditions for diffusion. Theory and Society 22: 487-511.

Taaffe, Robert. 1980. "Soviet regional development". In The Soviet Union Since Stalin, edited by Cohen, Rabinowitch and Sharlet, 155-178. Indiana: Indiana University Press.

Thornton, Patricia H. 2004. Markets from culture: Institutional logics and organizational decisions in higher education publishing. Stanford, CA: Stanford University Press.

. and William Ocasio. 2008. "Institutional logics". In The SAGE handbook of organizational institutionalism, edited by Greenwood R. \& Oliver C. \& Sahlin-Andersson, K. and Suddaby, R., 99-129. Thousand Oaks, CA: Sage.

— William Ocasio and Michael Lounsbury. 2012. The institutional logic perspective: A new approach to culture, structure and process. Oxford: Oxford University Press.

Von Laue, Theodore H. 1953. The high cost and the gamble of the Witte system: A chapter in the industrialization of Russia. The Journal of Economic History 13 (4): 425-48. 
1951. The industrialization of Russia in the writings of Sergej Witte. American Slavic and East European Review 10 (3): 177-90.

Weber, Alfred. (1909) 1969. Theory of the location of industries. Edited by Carl Friedrich. Chicago \& London: University of Chicago Press.

Zaleski, Eugene. 1980. Stalinist planning for economic growth, 1933-1952. Chapel Hill: University of North Carolina Press. 


\section{Appendix}

\section{Summary of data collection and review method}

The analysis was conducted as an extensive, qualitative literature review of Soviet and Western-based textbooks and journal articles discussing the theory and practices of Soviet industrial locations. The goal of the review process was to identify and categorize different elements and factors which influenced industrial location and spatial allocation decisionmaking in the Soviet Union from 1920s to 1960s. For this reason the industrial location principles presented by Koropeckyj (1965) and subsequent scholars were not taken as the point of departure, since the analysis was conducted to holistically view elements in the institutional environment and discover possible overlooked factors. The time period of the analysis was selected to depict the emergence of the institutional field of industrial location policy as well as the initial development of Soviet industrial geography. Elements of industrial location policy had become established by the 1960s and the development during the following decades did not dramatically alter prevailing economic regionalization. The reviewed publications were selected to represent two sources of industrial location literature: (1) Soviet textbooks of economic geography which consisted of broad presentations of national economic geography and more narrow studies of economic regions in the Soviet Union, and (2) textbooks and journal publications outside the Soviet Union, which analyzed the development, economic policies and strategies behind Soviet industrial location decisions. A criteria used for inclusion was that the author presented explicit claims or appraisals of factors which, in the author's view, influenced Soviet industrial location decision-making between 1920 and 1960. In addition, the claims, appraisals and analyses had to concentrate on location policies that either primarily or indirectly had an influence on actual industrial location decisions. The review process contained several phases. The first phase of data collection consisted of creating a comprehensive literature database around the subject literature. This phase was conducted using search engines (Web of Science, Google Scholar), available university library databases and bibliographies of the most relevant studies to identify relevant publications related to economic geography, economic history, economics and urban studies of Russia and the Soviet Union. The search results consisted of 217 publications, including 140 monographs, 59 articles and 18 book chapters. Of these, 30 publications were selected for in-depth analysis in the second phase based on criteria fulfillment and periodical and thematic relevance. From these publications, a total of 188 individual claims and appraisals were sketched (e.g. Lamberg et al. 2014) and arranged into an Excel database (available by request from the author). Economic 
logic contained 76 claims, military logic 21 claims (subject to censorship in Soviet publications) and regional logic 52 claims. During the later stages of research, the database was updated with ten selected articles from the Soviet journal Planovoye Khozyaystvo (Planning economy). Claims and appraisals were subjected to discursive analysis from which the proposed logic categories and their goals, expectations and outcomes were specified. A total of 39 outlier claims did not constitute any coherent entity of institutional logic and fell outside the analyzed categories. Logic entities were then evaluated in the light of institutional logic literature (e.g. Thornton et al. 2012) to ensure their fit with the theoretical framework. Finally, a description of each logic was summarized in narrative form in section 4 . 